\title{
ANTIOXIDANT ACTIVITY OF PLANT PARTS EXTRACTS FROM STERCULIA QUADRIFIDA R. BR.
}

\author{
GRACE SEREPINA SARAGIH ${ }^{1,2 *}$, SISWADI SISWADI ${ }^{1,3}$ \\ ${ }^{1}$ Department of Research and Development, Environment and Forestry Research and Development Institute of Kupang, Kupang, \\ Indonesia. ${ }^{2}$ Research and Development Center of Environmental Quality and Laboratory, Serpong, Banten, Indonesia. ${ }^{3}$ Department of \\ Research and Development, Environment and Forestry Research and Development Institute of Banjarbaru, Banjarbaru, \\ South Kalimantan, Indonesia. Email: graceserepina@gmail.com
}

Received: 10 April 2019, Revised and Accepted: 15 May 2019

\section{ABSTRACT}

Objective: Sterculia quadrifida R. Br. of Sterculiaceae family is locally known as "Faloak" in East Nusa Tenggara Province, Indonesia. S. quadrifida is used in folk medicine to treat hepatitis, rheumatism, and to recover stamina. The aim of this study was to determine the total flavonoids, total phenolic content (TPC), and antioxidant activity of extracts from different plant parts of S. quadrifida.

Methods: The sampled parts of S. quadrifida were non-stripped stem bark, new regrown stem bark, old regrown stem bark, root bark, branch bark, and leaves. Stem bark was classified into three categories, namely, bark that has never been peeled (non-stripped stem bark), old regrown stem bark (estimated to be $>6$ months after debarking), and new regrown stem bark (estimated to be $<6$ months after debarking). Total flavonoid content (TFC) was determined by colorimetric aluminum chloride method and TPC was measured using Folin-Ciocalteu's reagent. Antioxidant activity was determined with 2,2-diphenyl-1-picrylhydrazyl (DPPH).

Results: The concentrations of flavonoids in $S$. quadrifida extracts from different plant parts varied from $0.58 \pm 0.13$ to $1.25 \pm 0.10$ mg QE/g. The TPC in the extracts of different plant parts ranged between $8.61 \pm 0.09$ and $10.43 \pm 0.08 \mathrm{mg} \mathrm{GAE} / \mathrm{g}$. Branch bark has the highest total flavonoid and phenolic content. The extract of new regrown stem bark exhibited potent antioxidant activity with inhibitory concentration $\left(\mathrm{IC} \mathrm{C}_{50}\right)$ values of $2.51 \pm 0.03 \mu \mathrm{g} / \mathrm{ml}$.

Conclusion: This study demonstrated for the first time that extracts from different plant parts of $S$. quadrifida exhibited strong antioxidant activity. However, the total phenolic and flavonoid contents in S. quadrifida only indicated a weak correlation with its antioxidant activity.

Keywords: Sterculia quadrifida, Faloak, Antioxidant, Regrown bark.

(C) 2019 The Authors. Published by Innovare Academic Sciences Pvt Ltd. This is an open access article under the CC BY license (http://creativecommons. org/licenses/by/4. 0/) DOI: http://dx.doi.org/10.22159/ajpcr.2019.v12i7.33261

\section{INTRODUCTION}

Indigenous knowledge of medicinal plants provides the basis for the discovery of new drugs. Sterculia quadrifida $\mathrm{R}$. Br. is one of the most commonly used medicinal plants in East Nusa Tenggara Province, Indonesia. S. quadrifida bark is used to cure hepatitis, kidney disease, rheumatism, lower back pain, anemia, and stamina recovery [1]. This species belongs to the family Sterculiaceae which generally grows at an altitude of 1-1000 $\mathrm{m}$ asl. It has not been cultivated intensively, but can be propagated by seeds and cuttings [1]. S. quadrifida tree can grow up to $20 \mathrm{~m}$ high and flowers in April-June. The fruit is orange when ripe and contains 4-8 black seeds. In the Province of East Nusa Tenggara, $S$. quadrifida can be found on the islands of Timor, Sumba, Alor, Pantar, Rote, and Flores [2,3]. S. quadrifida is also known to grow in Australia [4] and India [5]. Aboriginal people in Australia use S. quadrifida leaves to treat stings and consume its young tree roots and seeds [6].

Medicinal plants that are harvested for their bark and roots are highly vulnerable to extinction due to excessive harvesting [7]. In Kupang city, S. quadrifida trees are frequently subjected to intensive peeling of their stem bark. In addition, people also tend to peel bark that has never been peeled because they think it is more efficacious than regrown bark. From these observations, the question arises: (1) Whether the antioxidant activity in the bark that has never been peeled is different from the regrown bark and (2) whether other parts of S. quadrifida trees also have potential to be used as remedies. Other studies of $S$. quadrifida have only determined the phenolic content, flavonoids, and antioxidants in the bark that has never been peeled $[8,9]$.

Phytochemical screening in a previous study showed that S. quadrifida barkcontains flavonoids, phenolic, alkaloids, and saponin [2]. Flavonoids are the largest group of phenol compounds [10]. Flavonoids are known to have antioxidant activity, as well as tannins which perform free radical scavenging activity. Medicinal plants that have high antioxidant activity are often used for the treatment of liver disease [11]. Medicinal plants are the main source of natural antioxidant. Antioxidant plays an important role as radical scavengers [12]. Phenolic compounds are the major contributor to the antioxidant capacity in plants [13]. Some studies indicate positive correlation of TPC and radical scavenging activity $[14,15]$. In the contrary, another study suggests a negative correlation between TFC and antioxidant activity [16]. The comparison of TPC, TFC, and antioxidant activity among different parts of $S$. quadrifida had not been studied. Therefore, the objectives of the present study were to determine the antioxidant activity, and co the TPC, and the TFC of ethanolic extracts from different parts of S. quadrifida tree.

\section{MATERIALS AND METHODS}

\section{Study site}

This study was conducted from June 2015 to January 2016 in Kupang, East Nusa Tenggara Province, Indonesia, located at S $10^{\circ} 07^{\prime} 40^{\prime \prime}-10^{\circ}$ $17^{\prime} 39^{\prime \prime}$ and E $123^{\circ} 31^{\prime} 35^{\prime \prime}-123^{\circ} 41^{\prime} 00^{\prime \prime}$. Kupang has a low annual average rainfall ( $1.290 \mathrm{~mm} /$ year). Its average humidity is $77 \%$ and its average temperature is $27.5^{\circ} \mathrm{C}$ [17]. The sampling locations are shown in Fig. 1.

\section{Plant materials}

The plant materials were identified in the Research Center for Biology, Indonesian Institute of Sciences. For the purpose of the present study, 14 S. quadrifida trees with diameters of $15-30 \mathrm{~cm}$ were selected from an altitude of $<300 \mathrm{~m}$ asl. The trees were selected based on a former 


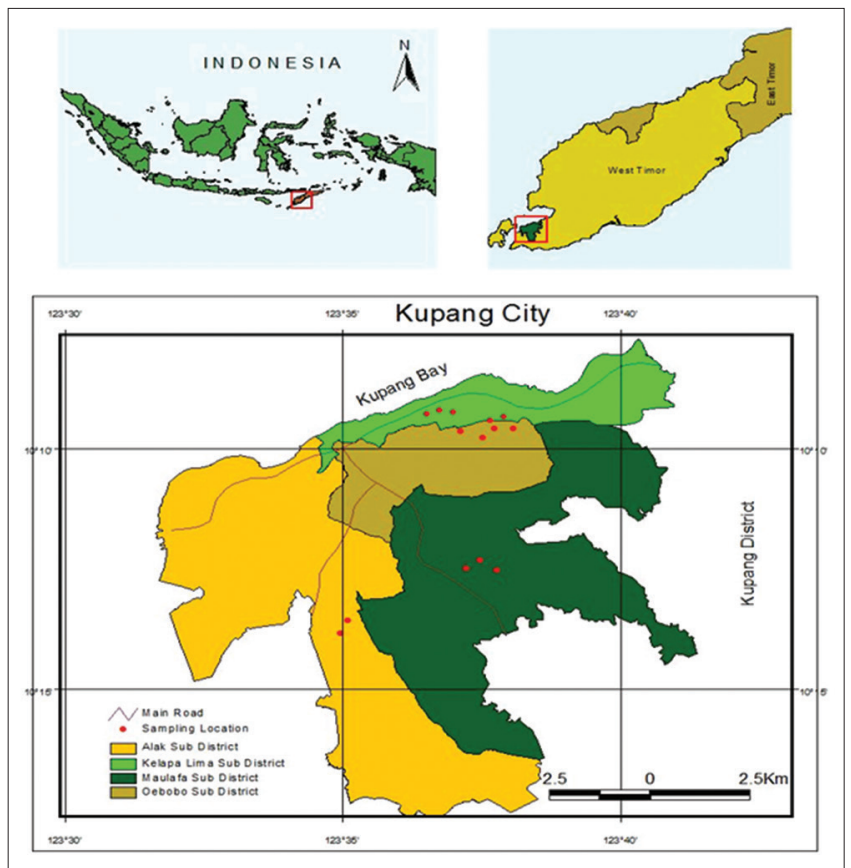

Fig. 1: Map of Sterculia quadrifida sampling location in Kupang, East Nusa Tenggara

study which revealed that the bark of trees in this diameter class and altitude had higher flavonoid content compared to those with diameter $\geq 15 \mathrm{~cm}$ or $\leq 30 \mathrm{~cm}$, and at altitudes of $>300 \mathrm{~m}$ asl [18].

Sampled plant parts of $S$. quadrifida used as the sample were non-stripped stem bark, new regrown stem bark, old regrown stem bark, root bark, branch bark, and leaves. Measurements were done on each tree sample for variables including diameter, approximate branch height, and branch-free bole length. The diameter was measured using diameter tape, while tree height and branch-free bole length were measured using a $2 \mathrm{~m}$ long stick. Root bark was obtained from the roots showing on the ground surface. Leaves collected were mature leaves. Barks samples were stripped vertically using a sharp knife to the limit of the cambium layer. The thickness was measured using a digital caliper. After the stripping, stem barks, branch bark, and root bark were weighed. Similarly, the leaves were also weighed. The number of samples obtained from each tree varied depending on the availability of the required materials.

\section{Extraction of plant parts}

The plant materials were dried at room temperature for 2 days and then kept in the oven for drying at $58^{\circ} \mathrm{C} \pm 2^{\circ} \mathrm{C}$ for 3 days. Stem bark, branch bark, and root bark were ground using a powder machine and then sieved with a 40 mesh sieve. Leaves were crushed with a blender. Subsequently, the yields were soaked in $95 \%$ ethanol with a ratio of 1:10, stirred for $30 \mathrm{~min}$, and left for $24 \mathrm{~h}$. The ethanol solutions were filtered twice using filter papers to obtain the filtrates which were then evaporated using a Vacuum Rotary Evaporator with a $60^{\circ} \mathrm{C}$ heating bath of. The thick extracts were poured into porcelain dishes to be reheated in a water bath at $60^{\circ} \mathrm{C}$ while stirred occasionally. The dried extracts generated from the process were then weighed and stored for further analysis.

\section{Determination of TFCs}

The TFC of the extracts was determined by the colorimetric method. The standard curve was made by quercetin. First, $5 \mathrm{mg}$ of quercetin was dissolved in, $0.3 \mathrm{ml}$ of $5 \%$ sodium nitrite. After $5 \mathrm{~min}, 0.6 \mathrm{ml}$ of $10 \%$ $\mathrm{AlCl}_{3}$ was added. After another $5 \mathrm{~min}, 2 \mathrm{ml}$ of $\mathrm{NaOH} 1 \mathrm{M}$ was added. Subsequently, $10 \mathrm{ml}$ of distilled water was added to the solution, which was then transferred into a cuvette, and the absorbance reading was done at $427 \mathrm{~nm}$ wavelength [19]. From this data, a regression equation between the concentration of quercetin and the absorption was created. TFC was expressed as milligrams of quercetin equivalents (QE) per $g$ of the dried fraction. Tests were carried out in triplicates.

\section{Determination of TPCs}

TPC values in the plant extracts were determined using procedure modified from [20]. The standard curve was drawn Gallic acid. First, $10 \mathrm{mg}$ of Gallic acid was dissolved in $0.5 \mathrm{ml}$ of Folin-Ciocalteu reagent and $7.5 \mathrm{ml}$ of Aqua Bidest. After $10 \mathrm{~min}$ at room temperature, $1.5 \mathrm{ml}$ of $20 \%$ sodium carbonate was added. The mixture was placed in a heated water bath at $40^{\circ} \mathrm{C}$ for $20 \mathrm{~min}$ and immediately cooled with liquid ice. The mixture was then diluted with Aqua Bidest until the volume reached $10 \mathrm{ml}$. Subsequently, it was transferred into a cuvette. The absorbance reading was done at $755 \mathrm{~nm}$ wavelength. Based on the result, a regression equation between the concentration of Gallic acid and the absorbance was made. TPC was expressed as milligrams of Gallic acid equivalents (GAE) per $\mathrm{g}$ of dried sample. Tests were carried out in triplicates.

\section{Determination of antioxidant activity}

Radical scavenging abilities of the extracts were determined by a procedure described by a previous study [21]. $50 \mu \mathrm{l}$ of a test sample of various concentrations were obtained to determine the $\mathrm{IC}_{50}$ values. $\mathrm{IC}_{50}$ is the concentration of extract/fraction that has $50 \%$ antioxidant activity of the control based on a linear regression equation. The samples were mixed with $1.0 \mathrm{ml}$ of $0.4 \mathrm{mM} \mathrm{DPPH}$ and $3.950 \mathrm{ml}$ of ethanol. The solutions were then homogenized through vortex mixing and left for $30 \mathrm{~min}$. The absorbance reading was done at $517 \mathrm{~nm}$ wavelength versus a blank consisting of $50 \mu \mathrm{l}$ of extract and $4.950 \mathrm{ml}$ of ethanol. The absorbance reading of the control was carried out on a control solution made of $1 \mathrm{ml}$ of DPPH and $4 \mathrm{ml}$ of ethanol. $\mathrm{IC}_{50}$ values $(\mu \mathrm{g} / \mathrm{ml}$ ) (concentrations of test samples that provided $50 \%$ inhibition of the DPPH radical) were calculated from the DPPH absorption curve. Vitamin C was used as the standard control.

\section{Data analysis}

All results were expressed as mean \pm standard deviation (SD). Statistical analyses were conducted using Microsoft Excel 2010 (Microsoft) and SPSS Statistics 22.0 (IBM). One-way analysis of variance combined with Least Significant Difference (LSD) post hoc comparison was used to determine the differences of means among the samples. The correlation between TPC, TFC, and antioxidant activity was analyzed using Pearson Correlation. $\mathrm{IC}_{50}$ was determined by linear regression curve.

\section{RESULTS}

It is rather difficult to find $S$. quadrifida trees with a diameter of $15-20 \mathrm{~cm}$. Consequently, most samples were obtained from trees with a diameter of $21-30 \mathrm{~cm}$ (Fig. 2). Of the two trees, it was not possible to obtain samples of old regrown bark due to intensive stripping. Tree dimensions, bark thickness, and leaves weight of the sampled trees are presented in (Table 1).

After stripping, S. quadrifida stem bark will regenerate and new regrown bark will grow differently from the surrounding bark (Fig. 3a). It has a lighter color than non-stripped or old regrown stem bark. In addition, it is easier to peel new regrown bark. Old regrown bark has the same color as non-stripped bark but is more concave than the surrounding bark (Fig. 3b). Old regrown bark is characterized by a layer that is almost similar to non-stripped bark (Fig. 3c), and it has thicker and harder cambium tissue. Other parts sampled from the trees were leaves (Fig. 4), root (Fig. 5,) and branches (Fig. 6).

\section{TPC, TFC, and antioxidant activity}

The level of TFC and TPC of S. quadrifida plant parts is presented in (Table 2).

The values are expressed as mean \pm SD of three replicate values. Different letters in the same column indicate significant difference of superscript by LSD test at $\mathrm{p}<0.01$. TPC was expressed as GAE $(\mu \mathrm{g} / \mathrm{ml})$ samples. TFC was expressed as $\mathrm{QE}(\mu \mathrm{g} / \mathrm{ml})$ samples. 
Table 1: Sterculia quadrifida tree dimensions, bark thickness, and weight per 10 leaves of tree samples

\begin{tabular}{|c|c|c|c|c|c|c|c|c|c|}
\hline \multirow[t]{2}{*}{ Tree } & \multirow[t]{2}{*}{ Dbh (cm) } & \multirow{2}{*}{$\begin{array}{l}\text { Tree } \\
\text { height (m) }\end{array}$} & \multirow{2}{*}{$\begin{array}{l}\text { Branch-free } \\
\text { bole length (m) }\end{array}$} & \multicolumn{5}{|c|}{ Bark thickness (mm) } & \multirow{2}{*}{$\begin{array}{l}\text { Leaves } \\
\text { Per } 10 \\
\text { leaves (g) }\end{array}$} \\
\hline & & & & $\begin{array}{l}\text { Non stripped } \\
\text { stem bark }\end{array}$ & $\begin{array}{l}\text { Branch } \\
\text { bark }\end{array}$ & $\begin{array}{l}\text { Old regrown } \\
\text { stem bark }\end{array}$ & $\begin{array}{l}\text { New regrown } \\
\text { stem bark }\end{array}$ & $\begin{array}{l}\text { Root } \\
\text { bark }\end{array}$ & \\
\hline 1 & 29 & 7 & 4.3 & 7.66 & 9.73 & 4.86 & 5.32 & 6.39 & 3.09 \\
\hline 2 & 19 & 4.7 & 1.5 & 13.6 & - & 4.92 & 4.63 & - & 2.38 \\
\hline 3 & 16 & 5 & 2.8 & 9.23 & 7.68 & 8.31 & 5.74 & 6.61 & 2.91 \\
\hline 4 & 21 & 5 & 3.7 & 11.17 & 7.97 & 4.62 & 10.14 & 8.56 & 2.42 \\
\hline 5 & 24 & 4 & 2.2 & 9.38 & 7.81 & 6.39 & 5.91 & 5.43 & 2.81 \\
\hline 6 & 21 & 3.4 & 1.9 & 7.96 & 9.63 & 4.44 & 5.6 & - & 2.41 \\
\hline 7 & 30 & 7 & 3.7 & 6.66 & 10.99 & 4.83 & 3.6 & 8.98 & 3.03 \\
\hline 8 & 23 & 5.5 & 3 & 13.66 & 9.46 & 3.92 & 3.06 & 11.88 & 1.61 \\
\hline 9 & 28 & 6 & 2.8 & 7.12 & 7.2 & 6.86 & 4.23 & 13.77 & 2.68 \\
\hline 10 & 26 & 8 & 5.5 & 11.25 & 4.6 & 5.47 & 6.1 & - & 1.72 \\
\hline 11 & 16 & 3.8 & 1.5 & 9.06 & 8.38 & - & - & - & 3.05 \\
\hline 12 & 26 & 6 & 3.4 & 11.66 & 10.4 & 5.77 & 5.72 & 6.49 & 2.61 \\
\hline 13 & 18 & 6.5 & 4.3 & 10.1 & 11.25 & - & 5.03 & - & 2.22 \\
\hline 14 & 27 & 5.5 & 1.5 & 12.94 & 6.7 & 6.08 & 6.08 & 7.88 & 1.77 \\
\hline Mean \pm SD & 23.14 & 5.32 & 2.95 & $10.10 \pm 2.3$ & $8.60 \pm 1.8$ & $5.54 \pm 1.2$ & $5.47 \pm 1.6$ & $8.44 \pm 2.6$ & $2.48 \pm 0.5$ \\
\hline
\end{tabular}

Remarks: (-) unavailable, $\mathrm{n}=14$. SD: Standard deviation

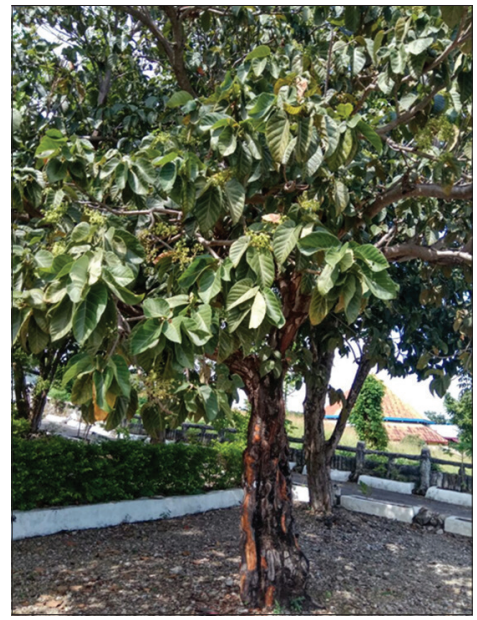

Fig. 2: Sterculia quadrifida tree
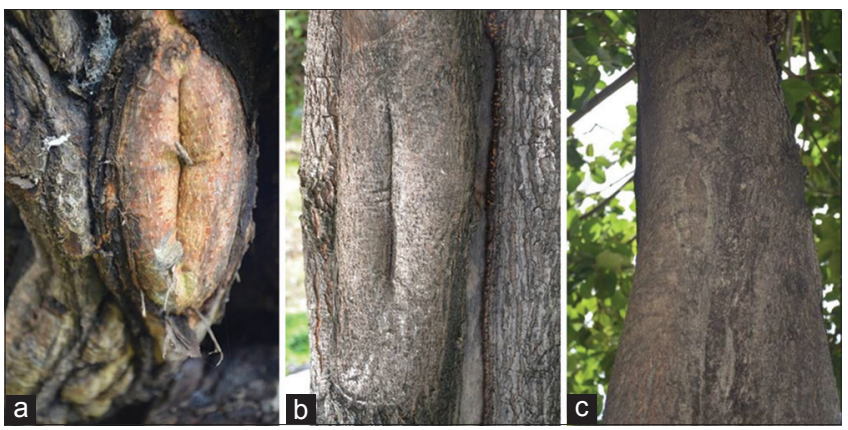

Fig. 3: Sterculia quadrifida (a) new regrown stem bark; (b) old regrown stem bark; (c) original non-stripped stem bark

The TFC values were $0.58 \pm 0.13 \mathrm{mg} Q \mathrm{QE} / \mathrm{g}, 0.59 \pm 0.08 \mathrm{mg} \mathrm{QE} / \mathrm{g}$, $0.88 \pm 0.06 \mathrm{mg} \mathrm{QE} / \mathrm{g}, 1.01 \pm 0.16 \mathrm{mg} \mathrm{QE} / \mathrm{g}, 1.15 \pm 0.07 \mathrm{mg} \mathrm{QE} / \mathrm{g}$, and $1.25 \pm 0.10 \mathrm{mg} \mathrm{QE} / \mathrm{g}$ for leaves, old regrown stem bark, non-stripped stem bark, new regrown stem bark, root bark, and branch bark, respectively. TFC of old regrown stem bark was insignificantly different ( $p>0.01$ ) from that of leaves, but was significantly different from other parts. Similarly, TPC of branch bark, old regrown stem bark, and new regrown stem bark was significantly different. TPC of the non-stripped bark and leaves was insignificantly different from each other $(p>0.01)$.

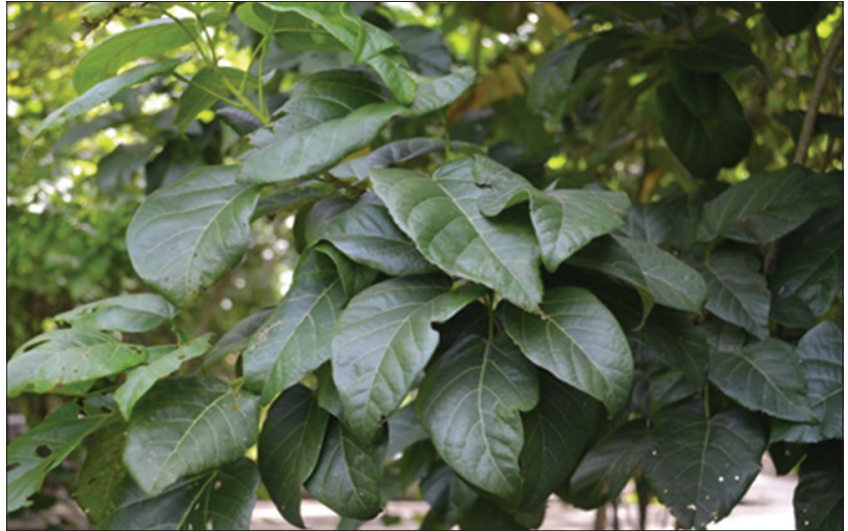

Fig. 4: Sterculia quadrifida leaves

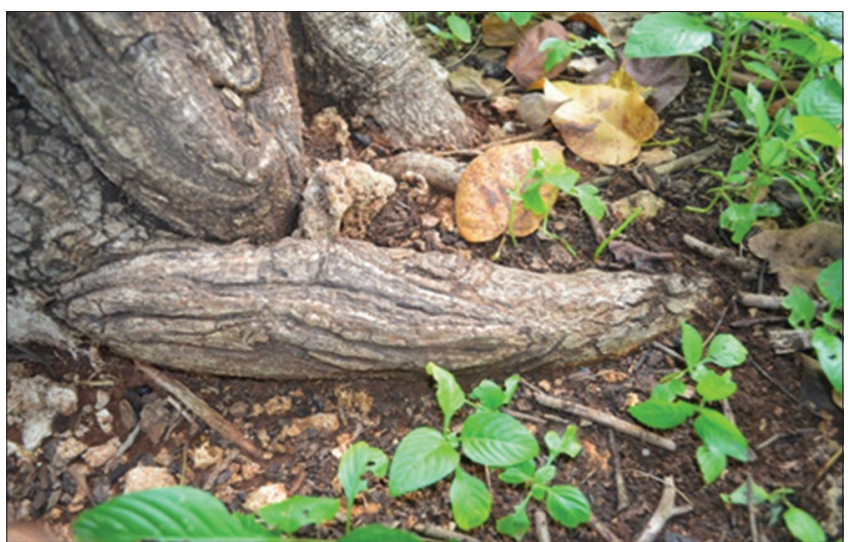

Fig. 5: Sterculia quadrifida root

The TPC values were $8.61 \pm 0.09 \mathrm{mg} \mathrm{GAE} / \mathrm{g}, 9.29 \pm 0.18 \mathrm{mg} \mathrm{GAE} / \mathrm{g}$, $9.33 \pm 0.15 \mathrm{mg} \mathrm{GAE} / \mathrm{g}, 9.50 \pm 0.09 \mathrm{mg} \mathrm{GAE} / \mathrm{g}, 9.77 \pm 0.21 \mathrm{mg} \mathrm{GAE} / \mathrm{g}$, and $10.43 \pm 0.08 \mathrm{mg} \mathrm{GAE} / \mathrm{g}$ for new regrown stem bark, leaves, nonstripped stem bark, root bark, old regrown stem bark and branch bark, respectively. Branch bark had the highest TFC and TPC. Leaves had the lowest TFC, while new regrown bark had the lowest TPC. The concentration of each extract required to inhibit radical by $50 \%\left(\mathrm{IC}_{50}\right)$ is shown in (Table 3). The antioxidant activities of the examined parts were significantly different $(\mathrm{P}<0.01)$. 
TFC values of $S$. quadrifida extracts showed a weak correlation with its antioxidant activity $(r=0.373, \mathrm{p}>0.01)$ (Table 4). Likewise, the TPC values of the ethanol extracts of $S$. quadrifida showed a weak correlation with its antioxidant activity $(r=0.211, \mathrm{p}>0.01)$.

\section{DISCUSSION}

Extraction is an important stage in the analysis of medicinal plants. Throughout the process of sample preparation and extraction, it must be ensured that no damage to or reduction in the content of the active compounds in the sample is caused [22]. The highest amount of bark was obtained from non-stripped stem bark. The largest percentage of yield was obtained from leaves while the smallest was obtained from branch bark (Table 5). The extract from non-stripped stem bark of S. quadrifida in the present study was lower than the extract obtained in a previous study [8], even though this study also used ethanol as a solvent. Some factors that affect the amount of extract are the parts of the plant, types of solvents [23,24], and the amount of bioactive content [25]. Moreover, immersion time can also affect the amount of polyphenol content obtained from the extract. The greater the yield the more efficient the extraction

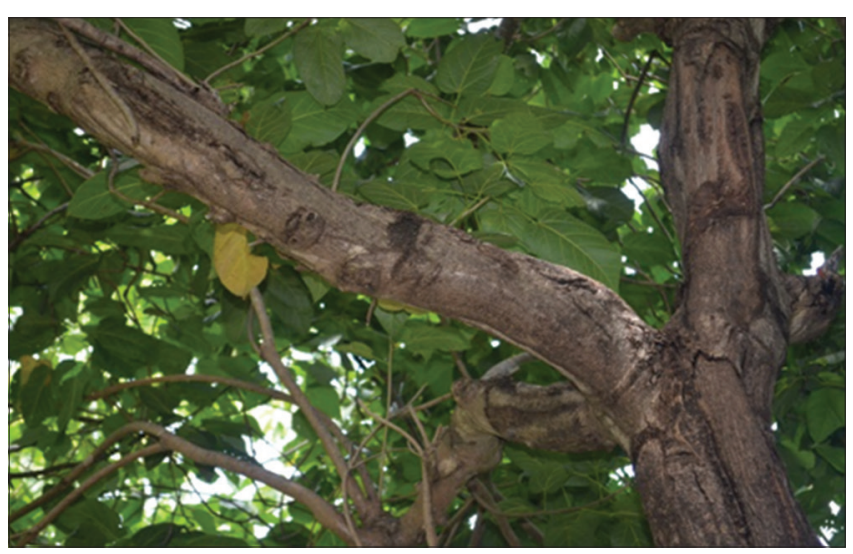

Fig. 6: Sterculia quadrifida branch

Table 2: Total flavonoid content and total phenolic content of ethanolic extracts in different parts of Sterculia quadrifida

\begin{tabular}{lll}
\hline Plant parts & TFC $(\mathrm{QE} \mu \mathrm{g} / \mathrm{ml})$ & TPC $(\mathrm{GAE} \mu \mathrm{g} / \mathrm{ml})$ \\
\hline Non-stripped stem bark & $0.88 \pm 0.06^{\mathrm{a}}$ & $9.33 \pm 0.15^{\mathrm{a}}$ \\
Branch bark & $1.25 \pm 0.10^{\mathrm{b}}$ & $10.43 \pm 0.08^{\mathrm{b}}$ \\
Root bark & $1.15 \pm 0.07^{\mathrm{b}, \mathrm{c}}$ & $9.50 \pm 0.09^{\mathrm{ca}}$ \\
Old regrown stem bark & $0.59 \pm 0.08^{\mathrm{d}}$ & $9.77 \pm 0.21^{\mathrm{d}}$ \\
New regrown stem bark & $1.01 \pm 0.16^{\mathrm{a}}$ & $8.61 \pm 0.09^{\mathrm{e}}$ \\
Leaves & $0.58 \pm 0.13^{\mathrm{d}}$ & $9.29 \pm 0.18^{\mathrm{a}, \mathrm{c}}$ \\
\hline
\end{tabular}

The values are expressed as mean \pm SD of three replicate values. Different letters in the same column indicate significant difference of superscript by LSD test at $\mathrm{p}<0.01$. TPC was expressed as Gallic acid equivalents (GAE $\mu \mathrm{g} / \mathrm{ml}$ ) samples. GAE: Gallic acid equivalent. TFC was expressed as quercetin equivalents ( $\mathrm{QE} \mu \mathrm{g} / \mathrm{ml})$ samples. SD: Standard deviation

Table 3: Total 2,2-diphenyl-1-picrylhydrazyl scavenging activities of the ethanolic extracts in different parts of Sterculia quadrifida

\begin{tabular}{ll}
\hline Plant parts & IC $_{\mathbf{5 0}}(\mu \mathrm{g} / \mathbf{m l}) \pm \mathbf{S D}$ \\
\hline Non stripped stem bark & $7.45 \pm 0.03^{* *}$ \\
Branch bark & $5.29 \pm 0.04^{* *}$ \\
Root bark & $9.72 \pm 0.07^{* *}$ \\
Old regrown stem bark & $3.43 \pm 0.12^{* *}$ \\
New regrown stem bark & $2.51 \pm 0.03^{* *}$ \\
Leaves & $4.96 \pm 0,01^{* *}$ \\
Vitamin C & $4.74 \pm 0.04$ \\
\hline
\end{tabular}

Each value is the average of three analyses \pm SD. ${ }^{* *}$ Significant at $\mathrm{p}<0.01$.

SD: Standard deviation method is. Ethanol is a suitable polar solvent for polyphenol extraction. Ethanol solvents produce a higher total phenolic and flavonoid content as well as a higher antioxidant activity than acetone solvents [26].

Polyphenols are a major component of plants that have a therapeutic effect [27]. The TFC and TPC were identified in branch bark. TPC and TFC of $S$. quadrifida stem bark in the present study were lower than those of the previous study. The previous study obtained TPC of $1.168 \pm 0.012$ (mg of GAE/g extract) and TFC of $6.618 \pm 0.123$ (mg of $\mathrm{QE} / \mathrm{g}$ extract) in which both values showed a close correlation with the antioxidant activity level [9]. The solvent used in the experiment affects the yield of phytochemical content [28]. Moreover, the differences in TPC and TFC were the result of the differences in location and time of sampling. During the rainy season, the intensity of solar radiation is lower; hence, it allegedly causes the lower content of secondary metabolites produced by plants during the season. Similarly, the phenol content has been reported to have a positive correlation with the intensity of solar radiation received by plants [29]. In addition, the content of secondary metabolites also correlates with precipitation, temperature, and nutrient content of the environment [30].

In addition to bark, leaves were another part of S. quadrifida that has been examined in previous studies. The results of phytochemical screening were detected flavonoids, steroids, terpenoids, tannins [4], amino acids, and fatty acids in the leaves of $S$. quadrifida [31]. Another study revealed that TPC, TFC, and antioxidant activity ( IC $_{50}$ ) of $S$. quadrifida leaves were, respectively, $52.46 \pm 0.63 \mathrm{mg} \mathrm{GAE} / \mathrm{g}, 70.5 \pm 1.45 \mathrm{mg} \mathrm{CE} / \mathrm{g}$ plant extract, and $2.190 .13 \pm 2.16(\mu \mathrm{g} / \mathrm{ml})$. Nevertheless, the total flavonoids and phenolic contents of $S$. quadrifida were much lower than Centella asiatica $(40.50 \mu \mathrm{g} / \mathrm{ml})$, Piper betle $(23 \mu \mathrm{g} / \mathrm{ml})$, and Morinda citrifolia $(85.20 \mu \mathrm{g} / \mathrm{ml})$ [32]. Variations in phenolic content and the level antioxidant activity in different parts of the plant can be due to differences in morphological structure and physiological activity [28]. For example, $\mathrm{IC}_{50}$ values of leaf, root, and bark of Abutilon indicum $\mathrm{L}$ extracted by methanol were 1052.28, 1124.78, and $1268.47 \mu \mathrm{g} / \mathrm{ml}$, respectively [24]. Moreover, the type of solvent also correlates with phenolic compounds and antioxidant activity values [33].

It is common for the local community to strip the bark that has never been stripped before. In fact, the analysis revealed that all bark tissues, including those of nonstripped, new regrown, and old regrown contained relatively the same TFC and TPC contents. Former study has also compared the phytochemical content of non-stripped bark and new regrown stem bark,

Table 4: Pearson's correlation coefficients between total flavonoid content, total flavonoid content, and inhibitory concentration of Sterculia quadrifida extracts

\begin{tabular}{llll}
\hline Variable & TFC & TPC & IC $_{\mathbf{5 0}}$ \\
\hline TFC & 1 & 0.211 & 0.373 \\
TPC & 0.211 & 1 & 0.211 \\
IC $_{50}$ & 0.373 & 0.211 & 1 \\
\hline
\end{tabular}

TFC: Total flavonoid content, TPC: Total phenolic content, IC s0 $_{50}$ Inhibitory concentration

Table 5: Rendemen of each plant part

\begin{tabular}{llll}
\hline Plant parts & $\begin{array}{l}\text { Dry } \\
\text { weight (g) }\end{array}$ & Extract (g) & Rendemen (\%) \\
\hline $\begin{array}{l}\text { Non-stripped stem } \\
\text { bark }\end{array}$ & 180.65 & 9.12 & 5.05 \\
$\begin{array}{l}\text { Old regrown stem } \\
\text { bark }\end{array}$ & 156.38 & 11.05 & 7.07 \\
$\begin{array}{l}\text { New regrown stem } \\
\text { bark }\end{array}$ & 114.13 & 11.4 & 9.99 \\
$\begin{array}{l}\text { Branch bark } \\
\text { Root bark }\end{array}$ & 195.3 & 9.62 & 4.93 \\
Leaves & 78.96 & 4.44 & 5.62 \\
\hline
\end{tabular}

Extraction of each part was done once, $n=1$ 
which also found similar finding [34]. These results indicate that new regrown stem bark has the potential to be utilized in medicine.

The lower the $\mathrm{IC}_{50}$ value, the better the antioxidant activity is. Quercetin is a polyphenolic derivative compound from flavonoids that can be isolated from plants. In several studies, quercetin has been utilized as a standard to evaluate the antioxidant potential of medicinal plants. The $\mathrm{IC}_{50}$ value of quercetin reported in previous studies varies from $1.08 \mu \mathrm{g} / \mathrm{ml}$ [35], $10.25 \pm 1.45 \mu \mathrm{g} / \mathrm{ml}$ [36], $14.52 \pm 2.12 \mu \mathrm{g} / \mathrm{ml}$ [37], to $60 \mu \mathrm{g} / \mathrm{ml}$ [38]. Based on these $\mathrm{IC}_{50}$ values, the antioxidant activity of $S$. quadrifida, overall, is equivalent or even stronger than that of quercetin. The strong antioxidant activity is in the range of $10-50 \mu \mathrm{g} / \mathrm{ml}$ [39]. Therefore, the antioxidant activity of the parts of $S$. quadrifida is classified as strong since the $\mathrm{IC}_{50}$ value is $<10 \mu \mathrm{g} / \mathrm{ml}$. The extract obtained from new regrown stem bark had higher antioxidant activity than those of other parts. The $\mathrm{IC}_{50}$ value of new regrown stem bark $(2.51 \mu \mathrm{g} / \mathrm{ml})$ is even stronger than the $\mathrm{IC}_{50}$ value of vitamin $\mathrm{C}(4.74 \mu \mathrm{g} / \mathrm{ml})$. The antioxidant activity of $S$. quadrifida was also stronger than other plants from Sterculiaceae family such as Pterospermum reticulatum $(182 \mu \mathrm{g} / \mathrm{ml})$ and Pterospermum rubiginosum $(166 \mu \mathrm{g} / \mathrm{ml})$ [40].

A study on the antioxidant activity of the bark of Sclerocarya birrea found that it has a significantly higher antioxidant activity after being repeatedly stripped method compared to being stripped just once [41]. This indicates that stripping has an effect on antioxidant activity of the bark. Regrown bark also has several secondary metabolites that cannot be found in original bark [34]. Other studies on the antioxidant activity of the barks of $S$. quadrifida reported the $\mathrm{IC}_{50}$ value of $4.81 \mu \mathrm{g} / \mathrm{ml}[8]$ and $7.29 \mu \mathrm{g} / \mathrm{ml}$ [9]. Nevertheless, these studies did not specify whether the analyzed bark was non-stripped or new regrown barks.

Previous studies revealed that TPC and TFC positively correlates with antioxidant activity $[32,38,42]$. On the contrary, in the present study, TFC only has a weak correlation with the antioxidant activity. It is similar to the results of study on phenolic content and antioxidant activity in Phyllanthus niruri [43], Pleurotus spp [44]. The weak correlation is assumed to be caused by other compounds that play a role in antioxidant activity. Thus, the TPC cannot be a benchmark for the antioxidant activity level. Another study showed a negative correlation between TPC and the DPPH free radical scavenging test [45]. This study was not able to identify the most dominant compounds that contribute to antioxidant activity. On the overall, all parts of $S$. quadrifida examined in this study had a very strong $\mathrm{IC}_{50}$ value.

\section{CONCLUSION}

This study revealed that some parts of $S$. quadrifida contain flavonoids, phenolics and show strong antioxidant activity that has the potential to be developed as a source of natural antioxidants. The strongest antioxidant activity was found in new regrown stem bark. Therefore, new regrown bark can be recommended for harvesting due to its high phytochemical content and for the purpose of sustainable harvesting. Further research is required to determine the presence of other compounds that contribute to antioxidant properties of S. quadrifida.

\section{ACKNOWLEDGMENTS}

The authors gratefully acknowledge financial support from the Environment and Forest Research and Development Institute of Kupang. We also thank Felipus Banani who supported plant material collection and Saya Kobayashi for proofreading the article.

\section{AUTHORS' CONTRIBUTIONS}

Grace Serepina Saragih collected the samples, analyzed the results, drafted, and revised the manuscript. Siswadi conducted sample analysis, analyzed the results, drafted, and revised the manuscript.

\section{CONFLICTS OF INTEREST}

The author declares that there are no conflicts of interest regarding the publication of this paper.

\section{REFERENCES}

1. Siswadi S, Raharjo AS, Pudjiono E, Saragih GS, Rianawati H. Utilization of faloak (Sterculia quadrifida R.Br.) bark as remedy in Timor Island. In: Njurumana G, Rahardjo SA, Riwu Kaho M, Kurniawan H, Hidayatullah M, editors. Seminar Nasional Biodiversitas Savana Nusa Tenggara. Kupang, Indonesia: Balai Penelitian dan Pengembangan Lingkungan Hidup dan Kehutanan Kupang; 2016.

2. Siswadi S, Rianawati H, Saragih GS, Sulistyo DH. The potency of faloak's (Sterculia quadrifida, R.Br.) active compunds as natural remedy. In: Rizal M, Januawati NM, Widyastuti Y, Brotokardono L, Efendi R, Rohadi D, et al., editors. International Seminar 'Forests and Medicinal Plants for Better Human Welfare. Bogor, Indonesia: Center for Forest Productivity Research and Development; 2014. p. 73-9.

3. Siswadi S, Saragih GS. Acute tocixity of Sterculia quadrifida R. Br bark ethanol extract on sprague-dawley rats. Trad Med J 2018;23:127-34.

4. Akter K, Barnes EC, Brophy JJ, Harrington D, Community Elders Y, Vemulpad SR, et al. Phytochemical profile and antibacterial and antioxidant activities of medicinal plants used by aboriginal people of New South Wales, Australia. Evid Based Complement Alternat Med 2016;2016:4683059.

5. Shanthi P, Tamilorasan G, Anitha K, Karthikeyan S. Film and pore diffusion modeling for adsorption of reactive red-4 onto Sterculia quadrifida seed shell waste as activated carbon. Rasayan J Chem 2014;7:229-40.

6. Lassak EV, McCarthy T. Australian Medicinal Plants. New South Wales: Methuen Australia; 1983.

7. Delvaux C, Sinsin B, Darchambeau F, Van Damme P. Recovery from bark harvesting of 12 medicinal tree species in Benin, West Africa. J Appl Ecol 2009;46:703-12.

8. Amin A, Wunas J, Anin YM. Determination of antioxidant activity of ethanolic extract of faloak (Sterculia quadrifida R. Br.) using DPPH (2, 2-diphenyl-1-picrylhydrazyl). J Fito Ind 2015;2:111-4.

9. Lulan TY, Fatmawati S, Santoso M, Ersam T. Antioxidant capacity of some selected medicinal plants in East Nusa Tenggara, Indonesia: The potential of Sterculia quadrifida R. Br. Free Radic Ant 2018;8:96-101.

10. Harborne JB. Phytochemical Methods. Bandung: Penerbit ITB; 1987. p. 78.

11. Govind P. Medicinal plants against liver diseases. Int Res J Pharm 2011;2:115-21.

12. Yadav A, Kumari R, Yadav A, Mishra J, Srivatva S, Prabha S. Antioxidants and its functions in human body - A review. Res Environ Life Sci 2016;9:1328-31

13. Vinson JA, Su X, Zubik L, Bose P. Phenol antioxidant quantity and quality in foods: Fruits. J Agric Food Chem 2001;49:5315-21.

14. Molan A, Ismail M, Nsaif R. Phenolic contents and antioxidant activity of peels and seeds of orange (Citrus sinensis) cultivated in Iraq. World J Pharm Pharm Sci 2016;5:473-82.

15. Lagha-Benamrouche S, Madani K. Phenolic contents and antioxidant activity of orange varieties Citrus sinensis L. and Citrus aurantium L. cultivated in Algeria: Peels and leaves. Ind Crop Prod 2013;50:723-30.

16. Othman A, Mukhtar NJ, Ismail NS, Chang SK. Phenolics, flavonoids content and antioxidant activities of 4 Malaysian herbal plants. Int Food Res J 2014;21:759.

17. Statistic Bureau of East Nusa Tenggara Province. Kupang city in 2015 figures. Kupang; 2016.

18. Siswadi S. Rendemen and Total Flavonoid Content of Faloak (Sterculia quadrifida R.Br.) Bark from Different Diameter Class and Altitude. Yogyakarta: Universitas Gadjah Mada; 2015.

19. Pękal A, Pyrzynska K. Evaluation of aluminium complexation reaction for flavonoid content assay. Food Anal Methods 2014;7:1776-82.

20. Chaovanalikit A, Wrolstad R. Total anthocyanins and total phenolics of fresh and processed cherries and their antioxidant properties. J Food Sci 2004;69:FCT67-72.

21. Marxen K, Vanselow KH, Lippemeier S, Hintze R, Ruser A, Hansen UP. Determination of DPPH radical oxidation caused by methanolic extracts of some microalgal species by linear regression analysis of spectrophotometric measurements. Sensors (Basel) 2007; 7:2080-95.

22. Sasidharan S, Chen Y, Saravanan D, Sundram KM, Yoga Latha L. Extraction, isolation and characterization of bioactive compounds from plants' extracts. Afr J Tradit Complement Altern Med 2011;8:1-10.

23. Syamsudin SR, Simanjuntak P. Antidiabetic activity of active fractions of Leucaena leucocephala (lmk) Dewit seeds in experiment model. Eur J Sci Res 2010;43:384-91

24. Saranya D, Sekar J, Adaikala RG. Assessment of antioxidant activities, phenol and flavonoid contents of different extracts of leaves, bark and 
root from the Abutilon indicum (1.) sweet. Asian J Pharm Clin Res 2017;10:88-94.

25. Dewatisari WF, Rumiyanti L, Rakhmawati I. Rendemen and phytochemical screening of Sanseviera sp. leaf. J Pen Perta Terp 2018; 17:197-202.

26. Olajuyigbe OO, Afolayan AJ. Phenolic content and antioxidant property of the bark extracts of Ziziphus mucronata willd. subsp. mucronata willd. BMC Complement Altern Med 2011;11:130.

27. Tsai K, Lin B, Perng D, Wei J, Yu Y, Cherng JM. Immunomodulatory effects of aqueous extract of Ocimum basilicum Linn. and some of its constituents on human immune cells. J Med Plant Res 2011;5:1873-83.

28. Stankovic MS, Niciforovic N, Mihailovic V, Topuzovic M, Solujic S. Antioxidant activity, total phenolic content and flavonoid concentrations of different plant parts of Teucrium polium L. subsp. polium. Acta Soc Bot Pol 2012;81:117-22.

29. del Baño MJ, Lorente J, Castillo J, Benavente-García O, del Río JA, Ortuño A, et al. Phenolic diterpenes, flavones, and rosmarinic acid distribution during the development of leaves, flowers, stems, and roots of Rosmarinus officinalis. Antioxidant activity. J Agric Food Chem 2003;51:4247-53.

30. Sampaio BL, Edrada-Ebel R, Da Costa FB. Effect of the environment on the secondary metabolic profile of Tithonia diversifolia: A model for environmental metabolomics of plants. Sci Rep 2016;6:29265.

31. Rajendran V. In vitro antiproliferative effect, cytotoxicity and apoptosis study of biogenic silver nanoparticles synthesized using Sterculia quadrifida leaf extract. J Eng Appl Sci 2018;13:1414-20.

32. Mustafa R, Hamid AA, Mohamed S, Bakar FA. Total phenolic compounds, flavonoids, and radical scavenging activity of 21 selected tropical plants. J Food Sci 2010;75:C28-35

33. Mashkor A. Phenolic content and antioxidant activity of fenugreek seeds extract. Int J Pharmacogn Phytochem Res 2014;6:841-4.

34. Fasola T, Akinloye A, Tossou M, Akoegninou A. The phytochemical and structural make-up of regrown and original tree barks used in ethnomedicine. World J Agric Res 2013;9:92-8.

35. Zuraida Z, Sulistiyani S, Sajuthi D, Suparto IH. Phenol, flavonoid and antioxidant activity of pulai (Alstonia scholaris R. br) bark extract. J Penelit Has Hutan 2017;35:211-9.

36. Nimmi O, George P. Evaluation of the antioxidant potential of a newly developed polyherbal formulation for antiobesity. Int $\mathrm{J}$ Pharm Pharm Sci 2012;4:505-10

37. Le Son H, Anh NP. Phytochemical composition, in vitro antioxidant and anticancer activities of quercetin from methanol extract of Asparagus cochinchinensis (Lour.) Merr. Tuber. J Med Plant Res 2013;7:3360-6.

38. Heo BG, Park YJ, Park YS, Bae JH, Cho JY, Park K, et al. Anticancer and antioxidant effects of extracts from different parts of indigo plant. Ind Crop Prod 2014;56:9-16.

39. Phongpaichit S, Nikom J, Rungiindamai N, Sakayaroj J, HutadilokTowatana N, Rukachaisirikul V, et al. Biological activities of extracts from endophytic fungi isolated from Garcinia plants. FEMS Immunol Med Microbiol 2007;51:517-25.

40. Jacob J, Sreejith K. Antioxidant and anti-inflammatory properties of Pterospermum rubiginosum heyne ex wight and arn and Pterospermum reticulatum wight and Arn (Sterculiaceae): An in vitro comparative study. Asian J Pharm Clin Res 2019;12:272-5.

41. Nndwammbi M, Ligavha-Mbelengwa M, Anokwuru C, Ramaite I. The effects of seasonal debarking on physical structure, polyphenolic content and antibacterial and antioxidant activities of Sclerocarya birrea in the Nylsvley nature reserve. S Afr J Bot 2018;118:138-43.

42. Jain A, Sinha P, Jain A, Vavilala S. Estimation of flavonoid content, polyphenolic content and antioxidant potential of different parts of Abrus precatorius (L.). Int J Pharm Pharm Sci 2015;7:157-63.

43. Harish R, Shivanandappa T. Antioxidant activity and hepatoprotective potential of Phyllanthus niruri. Food Chem 2006;95:180-5.

44. Sulistiany H, Sudirman LI, Dharmaputra OS. Production of fruiting body and antioxidant activity of wild Pleurotus. HAYATI J Biosci 2016;23:191-5.

45. Widyawati PS, Wijaya CH, Hardjosworo PS, Sajuthi D. Volatile compounds of Pluchea indica Less and Ocimum basillicum Linn essential oiland potency as antioxidant. HAYATI J Biosci 2013;20:117-26 